\title{
A simple gas analytical technique for the Dickson-type hydrothermal apparatus and its application to the calibration of MH, NNO and FMQ oxygen buffers
}

\author{
NoriaKi Kishima and Hitoshi SAKaI \\ Institute for Thermal Spring Research, Okayama University, Misasa-cho, Tottori-ken, 682-02, Japan
}

(Received September 19, 1983: Accepted December 13, 1983)

\begin{abstract}
A simple gas chromatographic technique was developed for the determination of dissolved gases in the aqueous samples taken out from Dickson-type hydrothermal apparatus, and $\mathrm{H}_{2}$ concentration was measured at temperatures below $500^{\circ} \mathrm{C}$ and pressures below 1,000 bars in aqueous systems containing magnetite-hematite, $\mathrm{Ni}-\mathrm{NiO}$ and fayalite-magnetite-quartz oxygen buffers. Oxygen-fugacity ratios between buffers $A$ and $B$ can be obtained by using a relation: $f_{\mathrm{O}_{2}}(A) / f_{\mathrm{O}_{2}}(\mathrm{~B})=\left[\mathrm{C}_{\mathrm{H}_{2}}(\mathrm{~B}) / \mathrm{C}_{\mathrm{H}_{2}}(\mathrm{~A})\right]^{2}$, where $\mathrm{C}_{\mathrm{H}_{2}}$ (A) and $\mathrm{C}_{\mathrm{H}_{2}}(\mathrm{~B})$ are equilibrium $\mathrm{H}_{2}$ concentrations in the systems A-water and B-water under the same P-T condition. Using a few $\mathrm{f}_{\mathrm{O}_{2}}$ ratios thus obtained, corrections were evaluated for the $\mathrm{f}_{\mathrm{O}_{2}}$-T relationships of the buffers given by a thermochemical compilation of ROBIE et al. (1979).
\end{abstract}

\section{INTRODUCTION}

The Dickson-type gold-cell apparatus (RYtUBA and Dickson, 1974; SEYFried et al., 1979) is an excellent device that enables us to conduct long-term hydrothermal experiments in chemically clean, large-volume reaction vessels and to take out solution samples easily from reacting systems without disturbing experimental conditions. This paper describes a simple technique of determining dissolved gases in these samples and its application to the calibration of oxygen fugacity vs. temperature relationships of magnetite-hematite $(\mathrm{MH})$, nickel-nickel oxide (NNO) and fayalite-magnetite-quartz (FMQ) oxygen buffers:

$$
\begin{aligned}
& 6 \mathrm{Fe}_{2} \mathrm{O}_{3}=4 \mathrm{Fe}_{3} \mathrm{O}_{4}+\mathrm{O}_{2} \\
& \text { hematite magnetite } \\
& 2 \mathrm{NiO}=2 \mathrm{Ni}+\mathrm{O}_{2} \\
& \begin{array}{l}
2 \mathrm{Fe}_{3} \mathrm{O}_{4}+3 \mathrm{SiO}_{2}=3 \mathrm{Fe}_{2} \mathrm{SiO}_{4}+\mathrm{O}_{2} \\
\text { magnetite quartz fayalite }
\end{array}
\end{aligned}
$$

The method of the calibration is as follows. Each of these buffers is put in water, equilibrated under appropriate P-T conditions and the hydrogen $\left(\mathrm{H}_{2}\right)$ concentration in water is measured. The oxygen buffer defines the oxygen fugacity $\left(\mathrm{f}_{\mathrm{O}_{2}}\right)$, the hydrogen fugacity $\left(\mathrm{f}_{\mathrm{H}_{2}}\right)$ and the $\mathrm{H}_{2}$ concentration in water $\left(\mathrm{C}_{\mathrm{H}_{2}}\right)$ in the system according to the relation:

$$
\begin{aligned}
\mathrm{f}_{\mathrm{O}_{2}} & =\left(\mathrm{f}_{\mathrm{H}_{2} \mathrm{O}} / \mathrm{K}_{\mathrm{W}} \mathrm{f}_{\mathrm{H}_{2}}\right)^{2} \\
& =\left(\mathrm{f}_{\mathrm{H}_{2} \mathrm{O}} / \mathrm{K}_{\mathrm{W}} \mathrm{Y}\right)^{2}\left(1 / \mathrm{C}_{\mathrm{H}_{2}}\right)^{2}
\end{aligned}
$$

where $f_{\mathrm{H}_{2} \mathrm{O}}$ is the water fugacity in the system, $\mathrm{K}_{\mathrm{W}}$ is the equilibrium constant for the reaction $\mathrm{H}_{2}+1 / 2 \mathrm{O}_{2}=\mathrm{H}_{2} \mathrm{O}$ and $\mathrm{Y}$ denotes the $\mathrm{f}_{\mathrm{H}_{2}} / \mathrm{C}_{\mathrm{H}_{2}}$ ratio. In all systems dealt with in this study, the aqueous phase can be regarded as pure water with respect to $f_{\mathrm{H}_{2} \mathrm{O}}$, and $f_{\mathrm{H}_{2}}$ is low enough to be proportional to $\mathrm{C}_{\mathrm{H}_{2}}$, so that the first term of the right side of eq. (4) becomes a quantity dependent only on temperature and pressure of water. The values of $\mathrm{Y}$ will be presented in another paper (KISHIMA and SAKAI, 1984), but without knowing them at present, we can get $\mathrm{f}_{\mathrm{O}_{2}}$ ratios for a pair of oxygen 
buffers $\mathrm{A}$ and $\mathrm{B}$ by measuring equilibrium $\mathrm{C}_{\mathrm{H}_{2}}$ 's in the aqueous systems containing each of these buffers under the same P-T conditions and by using a relation:

$$
\mathrm{f}_{\mathrm{O}_{2}}(\mathrm{~A}) / \mathrm{f}_{\mathrm{O}_{2}}(\mathrm{~B})=\left[\mathrm{C}_{\mathrm{H}_{2}}(\mathrm{~B}) / \mathrm{C}_{\mathrm{H}_{2}}(\mathrm{~A})\right]^{2}
$$

which can be derived easily from eq. (4) for the two buffers. The $f_{\mathrm{O}_{2}}$ ratio under 1 bar standard pressure is obtained by subtracting the effect of pressure $\mathrm{P}$ on the $\log \mathrm{f}_{\mathrm{O}_{2}}$ of each of the buffers which is evaluated by $-\Delta \mathrm{V}_{\mathrm{S}} \cdot(\mathrm{P}-1)$ / (RT 1n 10), where $\Delta V_{S}$ is the volume change of solids in the reactions (1), (2) and (3); the numerical values of $\Delta \mathrm{V}$ are $-3.548,-8.764$ and $-17.942 \mathrm{~cm}^{3} / \mathrm{mol}$ (RoBIE et al., 1979), respectively. Thus, the present calibration of $\mathrm{f}_{\mathrm{O}_{2}}-\mathrm{T}$ relationships of oxygen buffers is essentially a relative one.

\section{EXPERIMENTAL METHODS}

\section{Hydrothermal equipment and materials The}

Dickson-type apparatus used in this study is schematically illustrated in Fig. 1. The reaction vessel is a deformable, cylindrical gold bag of $2.7 \mathrm{~cm}$ diam., $26 \mathrm{~cm}$ long and $0.2 \mathrm{~mm}$ wall thickness. A gold capillary tube $(0.5 \mathrm{~mm}$ I.D., $2.0 \mathrm{~mm}$ O.D. and $42 \mathrm{~cm}$ long) leads the solution in the vessel to the sampling valve, which is an ordinary 3-way high pressure valve.

Temperature was monitored with three thermocouples placed at the both ends and the center of the pressure vessel and controlled to $\pm 0.5^{\circ} \mathrm{C}$ by a temperature recorder/controller according to the output from the central thermocouple. The accuracy of the thermocouplecontroller system was calibrated to about $\pm 0.7^{\circ} \mathrm{C}$ by using the melting-point method and a guaranteed thermocouple. The furnace winding is divided into three units and the power supplies to each of them were adjusted so as to bring the three temperature readings within $\pm 0.5^{\circ} \mathrm{C}$. The temperature difference between the wall and the interior of the pressure vessel has been confirmed to be negligible. Taking all possible errors into account, the

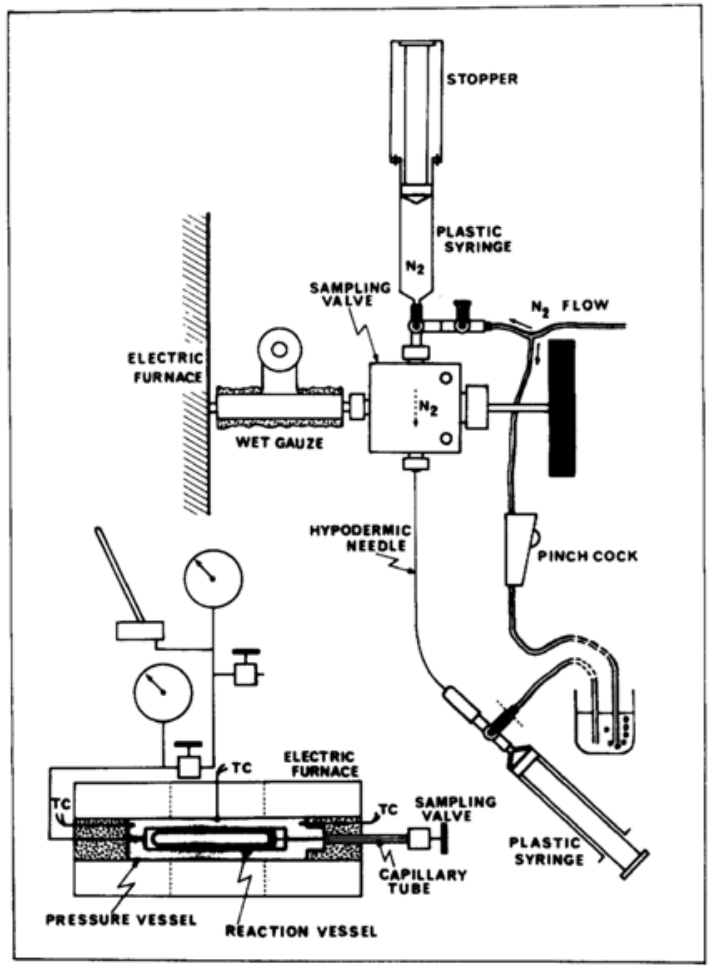

Fig. 1. Dickson-type gold-cell hydrothermal apparatus and the set-up for solution sampling and gas extraction.

uncertainty of individual temperature is estimated to be within $\pm 1.0^{\circ} \mathrm{C}$ and the reproducibility of temperature between separated runs is estimated to be within $\pm 0.6^{\circ} \mathrm{C}$. Pressure is adjusted to a desired level usually by controlling the amount of water outside the reaction vessel. Helium was added to the outside water so that any accidental leakage of the gold bag could be detected easily by the appearance of a helium peak on the gas chromatogram of the dissolved gases in the sample solution. The pressure was monitored by a monitoring gauge and its precise value was read on the occasion of sampling using a standard Bouldon gauge calibrated to a certified dead-weight pressure gauge. The uncertainty of pressure is estimated to be less than 1 bar. The experimental condition was limited below $500^{\circ} \mathrm{C}$ and 1 kbars by the durability of the pressure vessel. 
MH buffer was made by mixing $10 \mathrm{~g}$ each of chemical reagents $\mathrm{Fe}_{3} \mathrm{O}_{4}$ and $\mathrm{Fe}_{2} \mathrm{O}_{3}$. These materials were fine powder with grain diameters less than 0.2 and $6 \mu \mathrm{m}$, respectively, and gave $\mathrm{X}$-ray powder patterns identical with those of typical magnetite and hematite. Their purities (for $\mathrm{Fe}+\mathrm{O}$ ) were better than 99.9 wt. \% and $\mathrm{O} / \mathrm{Fe}$ atomic ratios were 1.36 and 1.49 , respectively. The slight analytical non-stoichiometry was ignored, because the above mixture obviously could stabilize only into a mixture of magnetite and hematite under the experimental conditions. NNO buffer was prepared from $20 \mathrm{~g}$ of fine powder of $\mathrm{NiO}$ (grain size $<8 \mu \mathrm{m}$, purity $>99.98 \%$ ) by reducing about a half of it with $\mathrm{H}_{2}$ in water in the reaction vessel. FMQ buffer was composed of $10 \mathrm{~g}$ of fayalite (grain size $<150 \mu \mathrm{m}$ ), $5 \mathrm{~g}$ of $\mathrm{Fe}_{3} \mathrm{O}_{4}$ (the same reagent as above) and $2 \mathrm{~g}$ of $\mathrm{SiO}_{2}$ (precipitated silica identified with quartz by its X-ray powder pattern, purity $>99.98 \%$ ). The fayalite used here was synthesized by heating a stoichiometric mixture of $\mathrm{Fe}_{2} \mathrm{O}_{3}$ (the same reagent as above), $\mathrm{Fe}$ (reduced iron, metallic impurity $<0.04 \mathrm{wt}$. $\%$ ) and $\mathrm{SiO}_{2}$ (the same reagent as above) at $1,000^{\circ} \mathrm{C}$ in an evacuated, sealed silica tube. The synthetic product (well-crystallized fayalite) contained small amounts of wüstite and quartz but it was used without further treatment since wüstite is unstable under the experimental conditions. The water used was basically deairated, de-ionized water but oxygen or hydrogen was added occasionally in order to condition the oxygen buffers.

Determination of $\mathrm{H}_{2}$ in the aqueous sample

The sampling of the hydrothermal solution and the extraction of dissolved gases in the sample were conducted by using a set-up illustrated in Fig. 1. Two plastic syringes $(12 \mathrm{ml}$ in capacity; silicone oil was used as lubricant for the piston), three plastic 3-way stopcocks, a hypodermic needle $(15 \mathrm{~cm}$ long; it can be fastened to the sampling valve by the aid of a small piece of metal pipe cemented at the end of the needle) and other parts shown in Fig. 1 are all inexpensive materials.
The sampling procedure is as follows. The upper syringe containing a known amount (ca. $9 \mathrm{~cm}^{3}$ ) of nitrogen $\left(\mathrm{N}_{2}\right)$, and other parts except the lower syringe and stopcock, are attached to the sampling valve as illustrated in Fig. 1. A small fraction (ca. $0.5 \mathrm{ml})$ of solution is discarded. Nitrogen is let flow through the sampling valve and the needle, the moisture in the flow path is expelled, the lower syringe is attached and, after its inner space is flushed with $\mathrm{N}_{2}$, the piston of the lower syringe is pushed up, the pressure of $\mathrm{N}_{2}$ flow is released and the flow path is cut off enclosing a small, known amount of $\mathrm{N}_{2}$. An appropriate amount (ca. $2 \mathrm{ml}$ ) of solution is taken to the lower syringe (note here that the solution sample is cooled efficiently on the way to the syringe), the $\mathrm{N}_{2}$ in the upper syringe is also transferred there, the lower syringe (kept attached to the accepter of the needle) is shaken for about 3 minutes, and then the resulting gas mixture is transferred back to the upper syringe and submitted to the following gas chromatographic analysis. The solution remaining in the lower syringe is weighed and submitted to chemical analyses, if necessary. Our sampling set-up was tested and found satisfactory with regard to leak-out of $\mathrm{H}_{2}$, leak-in of air and $\mathrm{H}_{2}$ evolution from the materials used, as long as all the above procedures are carried out in succession.

The gas analysis was performed by using a Shimazu GC-6AM gas chromatograph equipped with a thermal conductivity detector (TCD), a dual separating column ( $3 \mathrm{~mm}$ I.D. $\times 5 \mathrm{~m}$ ) packed with Porapak-Q (Waters Associate Ltd.; 80-100 mesh), and a constant-volume $\left(2 \mathrm{~cm}^{3}\right)$ gas sampler. The carrier gas was $\mathrm{N}_{2}$ and the column temperature was set at $60^{\circ} \mathrm{C}$. To obtain a higher sensitivity for $\mathrm{H}_{2}$ analysis, argon might have been better than $\mathrm{N}_{2}$ for the carrier gas (and hence the stripping gas as well). The output of the chromatograph was fed to a strip chart recorder and a data processor (Shimazu C-R1A 'Chromatopac') in order to measure peak areas. The sensitivity of the gas chromatographic system was calibrated under a standardized set of conditions with accuracies 
ranging from 0.7 to $5 \%$ for $\mathrm{H}_{2}$ concentrations ranging from $100 \%$ to $14 \mathrm{ppm}$ using mixtures of $\mathrm{N}_{2}$ and $\mathrm{H}_{2}$ of known compositions. In calculating the $\mathrm{C}_{\mathrm{H}_{2}}$ in the solution sample, corrections were made for the water vapor present in the gas mixture sample and for the drift of sensitivity of the gas chromatographic system. The reliability of the analytical scheme was confirmed by measuring solubility of $\mathrm{H}_{2}$ in water at a room temperature. Throughout this report, $\mathrm{C}_{\mathrm{H}_{2}}$ is given in $\mathrm{cm}^{3}$ of $\mathrm{H}_{2}$ at STP dissolved in $1 \mathrm{~g}$ of water.

\section{EXPERIMENTAL OBSERVATIONS and RESULTS}

$C_{\mathrm{H}_{2}}$ in the $\mathrm{MHW}$ system An example of variation with time in $\mathrm{H}_{2}$ concentration in the MHW system is shown in Fig. 2* The system was first brought up to $420^{\circ} \mathrm{C}$ and 982 bars in 5 hours and kept at the condition afterward (stage (a)). The $\mathrm{C}_{\mathrm{H}_{2}}$ passed a peak after 9 hours, returned quickly to a basic, slowly rising curve and finally reached a constant level after about $170 \mathrm{hr}$. These features can be explained respectively by quick decomposition of organic

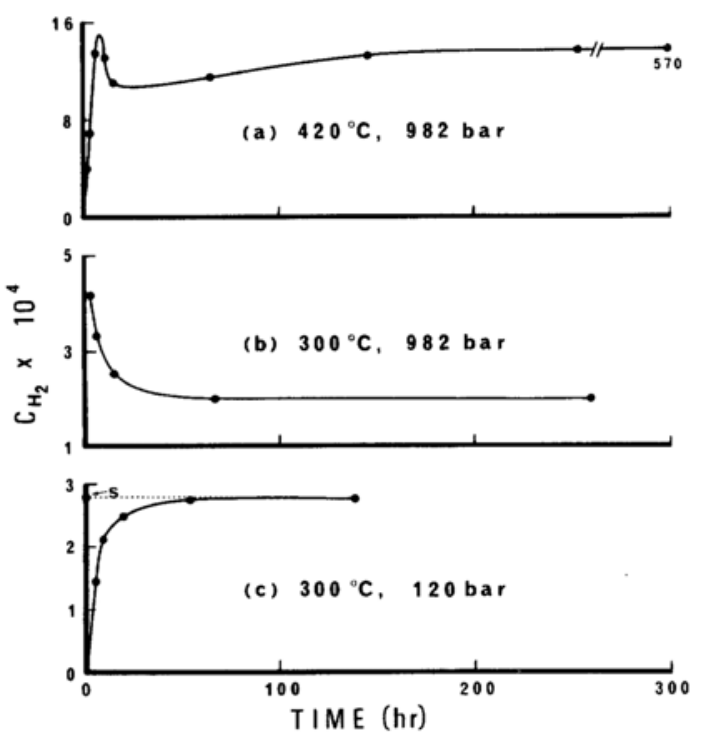

Fig. 2 Variation with time of $\mathrm{H}_{2}$ concentration in a virgin $M H W$ system.

* Here and hereafter, $\mathrm{W}$ denotes water.
Table 1. Equilibrium $\mathrm{H}_{2}$ concentrations in the $\mathrm{MHW}$ system

\begin{tabular}{cccccc}
\hline \hline $\mathrm{T}\left({ }^{\circ} \mathrm{C}\right)$ & $\mathrm{P}($ bar $)$ & $\mathrm{C}_{\mathrm{H}_{2} \times 10^{4}}$ & $\left.\mathrm{~T}{ }^{\circ} \mathrm{C}\right)$ & $\mathrm{P}($ bar $)$ & $\mathrm{C}_{\mathrm{H}_{2}} \times 10^{4}$ \\
\hline 296 & 986 & 2.09 & 387 & 296 & 25.5 \\
- & 720 & 2.23 & 416 & 999 & 13.0 \\
- & 478 & 2.33 & - & 853 & 14.3 \\
- & 286 & 2.39 & - & 707 & 16.8 \\
- & 98 & 2.89 & - & 558 & 21.0 \\
326 & 972 & 3.65 & - & 430 & 29.8 \\
- & 575 & 4.13 & - & 365 & 48.3 \\
- & 286 & 5.05 & 455 & 980 & 22.5 \\
- & 145 & 5.76 & - & 478 & 63.7 \\
356 & 974 & 5.82 & 456 & 723 & 31.4 \\
- & 575 & 7.05 & 486 & 974 & 32.4 \\
- & 332 & 9.01 & - & 773 & 42.8 \\
- & 238 & 10.9 & - & 624 & 60.4 \\
- & 198 & 12.6 & - & 548 & 79.5 \\
386 & 286 & 25.6 & - & 503 & 99.1 \\
387 & 757 & 10.3 & - & 485 & 112 \\
- & 731 & 10.4 & - & 440 & 133 \\
- & 623 & 11.6 & - & 380 & 176 \\
- & 336 & 19.4 & 487 & 974 & 33.2 \\
\hline
\end{tabular}

impurities included in the starting material, reactive nature of hematite or of an oxidation layer formed over magnetite by the action of water and the oxygen dissolved in the water (this time the water was saturated with air), and slow change of the solid phase to the stable magnetite-hematite assemblage. Then, the temperature was lowered to $300^{\circ} \mathrm{C}$ maintaining the previous pressure (stage (b)). The $\mathrm{C}_{\mathrm{H}_{2}}$ value reached a new equilibrium level in 3 days, more quickly than before in spite of the lower temperature. In the next stage (c), after the system was stabilized at $300^{\circ} \mathrm{C}$ and 120 bars and a sample was taken (marked by ' $\mathrm{S}$ '), an aliquot of water saturated with oxygen was injected into the reaction vessel. The $\mathrm{H}_{2}$ in the vessel was killed immediately but recovered the initial concentration at ' $\mathrm{S}$ ' within 3 days.

The measured equilibrium $\mathrm{C}_{\mathrm{H}_{2}}$ values of MHW systems are listed in Table 1 and shown in Fig. 3. Most of these data are mean values from replicate measurements that agreed within $\pm 1.5 \%$ ( $\pm 4 \%$ in the worst case). We allotted times longer than 7, 4 and 2 days at 300, 400 and $500^{\circ} \mathrm{C}$, respectively, for the re-equilibration of the system after a change of pressure or temperature. The lower limit of experimental 


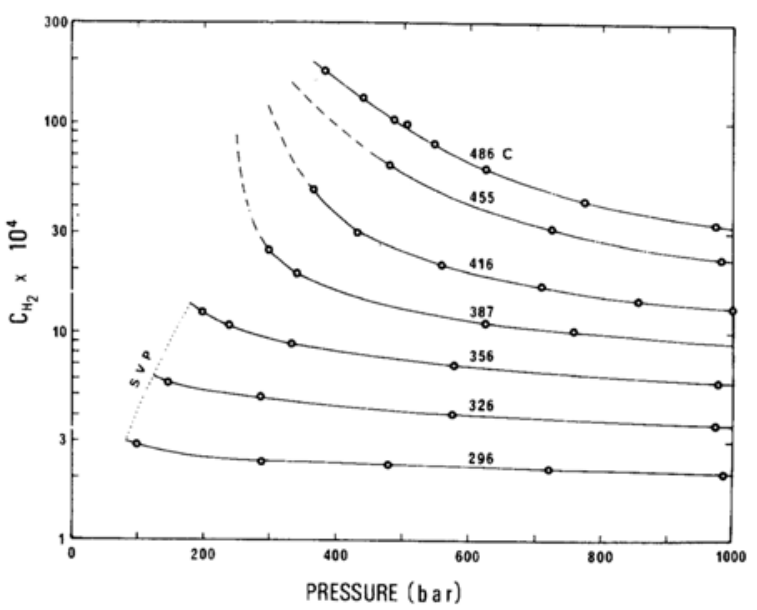

Fig. 3 Equilibrium $\mathrm{C}_{\mathrm{H}_{2}}$ values in the $\mathrm{MHW}$ system. Isotherms for 455,416 and $387^{\circ} \mathrm{C}$ are extrapolated by using $Y$ values given by KISHIMA and SAKAI (1984). SVP: the saturation vapor pressure curve of water.

temperature $\left(\sim 295^{\circ}\right)$ was imposed by the decrease in the accuracy of hydrogen determination with decreasing $\mathrm{C}_{\mathrm{H}_{2}}$.

\section{$\mathrm{C}_{\mathrm{H}_{2}}$ in the $\mathrm{NNOW}$ system Equilibration} curves of $\mathrm{C}_{\mathrm{H}_{2}}$ in the NNOW system initiated under out-of-equilibrium conditions can be featured by a superposition of a fast and a slow processes, and these are supposed to be the redox reactions on the surface of $\mathrm{Ni}$ or $\mathrm{NiO}$ grains and the diffusion of hydrogen into or out of $\mathrm{Ni}$ grains, respectively. It should be noted that, owing to the slow process, the NNOW system requires considerably long time to attain the true equilibrium. Even in the present NNOW system which comprised fine powder of $\mathrm{Ni}$, the time necessary for equilibration was about 5 to 6 times as long as that for the MHW system under the similar conditions.

The measured equilibrium $\mathrm{C}_{\mathrm{H}_{2}}$ values of the NNOW system and the differences of log $\mathrm{f}_{\mathrm{O}_{2}}$ between $\mathrm{MH}$ and $\mathrm{NNO}$ buffers calculated therefrom are given in Table 2. The activity of $\mathrm{Ni}$ was assumed to be unity in the calculation of the $\log \mathrm{f}_{\mathrm{O}_{2}}$ difference on the basis of the facts
Table 2. Equilibrium $\mathrm{H}_{2}$ concentrations in the $\mathrm{NNOW}$ system, corresponding values in the $M H W$ system and $\log \mathrm{fO}_{2}$ differences $\left(\Delta \log \mathrm{fO}_{2}\right)$ between $\mathrm{MH}$ and $\mathrm{NNO}$ buffers

\begin{tabular}{cccccc}
\hline \hline $\mathrm{T}\left({ }^{\circ} \mathrm{C}\right)$ & $\mathrm{P}(\mathrm{bar})$ & $\begin{array}{c}\mathrm{C}_{\mathrm{H}_{2}} \times 100 \\
\text { in NNOW }\end{array}$ & $\begin{array}{c}\mathrm{C}_{\mathrm{H}_{2}} \times 10^{4} \\
\text { in MHW }\end{array}$ & $\begin{array}{c}\Delta \log \mathrm{f}_{\mathrm{O}_{2}} \\
\text { at T, } \mathrm{P}\end{array}$ & $\begin{array}{c}\Delta \log \mathrm{fO}_{\mathrm{O}_{2}} \\
\text { at T, } 1 \text { bar }\end{array}$ \\
\hline 486 & 980 & 28.3 & 32.6 & 3.88 & $3.91 \pm 0.04 \mathrm{a}$ \\
466 & 978 & 20.8 & 26.2 & 3.80 & $3.84 \pm 0.04$ \\
396 & 337 & 20.1 & 26.2 & 3.77 & $3.81 \pm 0.05$ \\
355 & 980 & 3.59 & 5.70 & 3.60 & $3.64 \pm 0.05$ \\
327 & 195 & 3.66 & 5.50 & 3.65 & $3.66 \pm 0.06$ \\
\hline
\end{tabular}

a Errors are for the possible temperature discrepancy of $\pm 0.6^{\circ} \mathrm{C}$ between $\mathrm{MHW}$ and NNOW systems and for the possible analytical error of $\pm 2 \%$ in the $\mathrm{C}_{\mathrm{H}_{2}}$ ratios.

that (1) the $\mathrm{H} / \mathrm{Ni}$ atomic ratio in the $\mathrm{Ni}$ grains, which can be calculated from the $\mathrm{C}_{\mathrm{H}_{2}}$ data, the $\mathrm{Y}$ values given by KISHIMA and SAKAI (1983) and the reported solubility data for hydrogen in Ni (STAFFord and MCLELlaN, 1974), remained at about $1.6 \times 10^{-4}$ even in the case of $486^{\circ} \mathrm{C}$ and 980 bars, ant that (2) gold did not deposit on the Ni grains under the experimental conditions, as confirmed by SEM observation of the solid phase after the run.

$C_{\mathrm{H}_{2}}$ in the FMQW system The $\mathrm{C}_{\mathrm{H}_{2}}$ values in the FMQW system were measured only at $487^{\circ} \mathrm{C}$ and 970 bars; the temperature is just above the low-temperature boundary (which falls within $478-484^{\circ} \mathrm{C}$ (FLASCHEN and OSBORN, 1957)) of the stability field of fayalite in the presence of water and quartz. All the measured $\mathrm{C}_{\mathrm{H}_{2}}$ data are given in Table 3. Somewhat higher values of the earlier measurements may be attributed to the wüstite contained in the starting material. A mean value of $\mathrm{C}_{\mathrm{H}_{2}}=0.530 \pm 0.007$ is obtained from the later seven measurements but the actual error range is estimated to be about \pm 0.015 taking possible temperature and analytical errors into account.

The water in this system is saturated with quartz under the given P-T condition (in fact, 2290-2335 ppm of silica was observed in agreement with the data of KENNEDY, 1950, and FOURNIER and POTTER, 1982). If the solution 
Table 3. Measured $\mathrm{H}_{2}$ concentrations in the FMQW system at $487^{\circ} \mathrm{C}$ and 970 bars

\begin{tabular}{cl}
\hline \hline $\begin{array}{c}\text { Lapse of time } \\
\text { (Days) }\end{array}$ & $\mathrm{C}_{\mathrm{H}_{2}}$ \\
\hline 5 & $0.575^{\mathrm{a}}$ \\
16 & 0.630 \\
22 & 0.630 \\
75 & $0.543,0.518^{\mathrm{a}}$ \\
87 & 0.530 \\
93 & $0.525^{\mathrm{a}}$ \\
102 & $0.538,0.525,0.531$ \\
\hline a $H_{2}$ was injected after these samplings.
\end{tabular}

stays long in the capillary tube, quartz will precipitate and eventually clog the tube. In order to avoid this trouble, water was injected into the reaction vessel after every sampling except for three samplings that were immediately followed by the next sampling. Sometimes $10-15 \mathrm{~cm}^{3}$ at STP of $\mathrm{H}_{2}$ and sometimes no $\mathrm{H}_{2}$ was put into the vessel together with the water. The observed constancy of $\mathrm{C}_{\mathrm{H}_{2}}$, therefore, can be regarded as a manifestation of the buffering function of FMQ assemblage.

Though the concentrations of dissolved silica and $\mathrm{H}_{2}$ are fairly high, the solute/solvent molar ratio remains at about $8 \times 10^{-4}$ and therefore the $f_{\mathrm{H}_{2} \mathrm{O}}$ can still be taken to be equal to that of pure water. Then, from the above mean $\mathrm{C}_{\mathrm{H}_{2}}$ value and the corresponding value of the MHW system, $3.28 \pm 0.10 \times 10^{-3}$, the $\log \mathrm{f}_{\mathrm{O}_{2}}$ difference between $\mathrm{MH}$ and FMQ buffers is calculated to be $4.417 \pm 0.05$ at $487^{\circ} \mathrm{C}$ and 970 bars or $4.513 \pm 0.05$ at the same temperature and 1 bar.

\section{Discussion}

We will now discuss the $f_{\mathrm{O}_{2}}$-T relationships of individual oxygen buffers on the basis of the data obtained above and related data in the literature. The thermochemical compilation of RoBIE et al. (1979) (abbreviated to RHF in the following) will be chosen as a main reference and corrections will be evaluated for the $\log \mathrm{f}_{\mathrm{O}_{2}}-1 / \mathrm{T}$ relationships of $\mathrm{MH}, \mathrm{NNO}$ and FMQ buffers given by RHF.

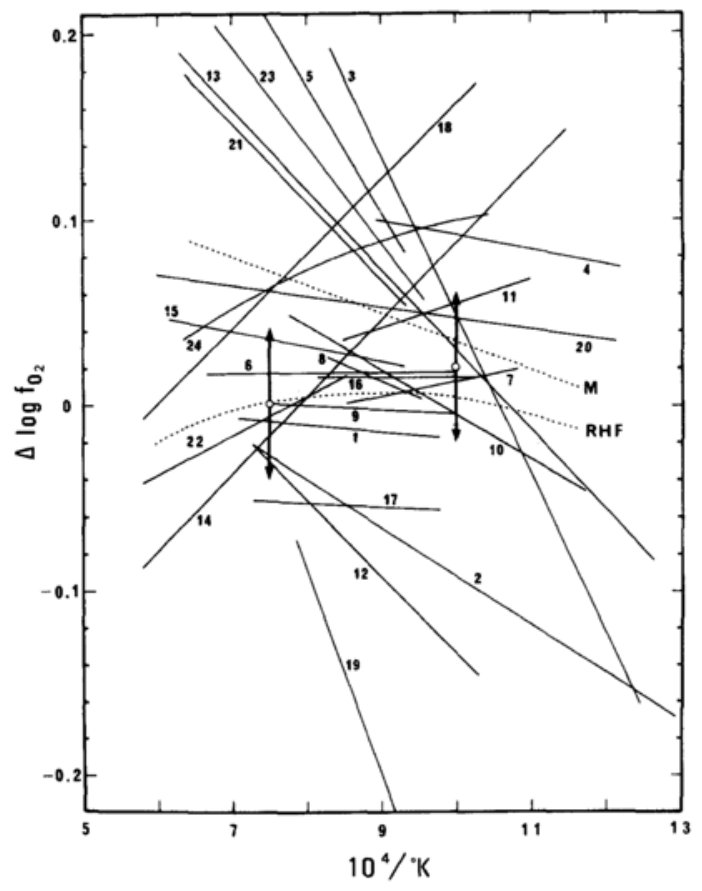

Fig. 4 Comparison of reported $\log \mathrm{fO}_{2}-1 / T$ scales of $N N O$ buffer determined by the high-temperature emf method. $\Delta \log \mathrm{fO}_{2}$ denotes the difference from a temporary scale: $\log \mathrm{fO}_{2}(\mathrm{~atm})=8.9-24500 / T$. Data sources: 1, KIUKKOLA and WAGNER (1957); 2, MARKIN and BONES (1962); 3, BARBI (1964); 4, ALCOCK and BELFORD (1964); 5, TAYLOR and SCHMALZRIED (1964); 6, TRETYKOV and SCHMALZRIED (1965); 7, STEELE and ALCOCK (1965); 8, SELLARS and MAAK (1966); 9, PIZZINI and MORLOTTI (1967); 10, ANTILL and WARBURTON (1967); 11, CHARETTE and FLENGAS (1968); 12, MORIYAMA et al. (1969); 13, HUEBNER and SATO (1970); 14, FISCHER and PATEISKY (1970); 15, OISHI et al. (1972); 16, KLINEDINST and STEVENSON (1972); 17, VASIL'EVA et al. (1975); 18, IWASE et al. (1975); 19. MOSER et al. (1975); 20, BERGLUND (1976); 21, MYERS and GUNTER (1979); 22, KEMORI et al. (1979); 23, SCHWAB and KÜSTNER (1981); 24, JACOBSSON and ROSÉN (1981). Two marks with arrows indicate the positions where these data converge; dashed line $M$, the mean of these data; dashed line $\mathrm{RHF}$, the $\log \mathrm{fO}_{2}$ (atm)-1/T relation given by ROBIE et al. (1979). 
The NNO buffer is the most convenient one to be discussed first, since (1) its buffering reaction involves the smallest mole number of compounds, (2) comparatively good thermochemical data are available for its components, and (3) its $\mathrm{f}_{\mathrm{O}_{2}}-\mathrm{T}$ relation at higher temperatures has been measured repeatedly by the solidelectrolyte emf method.

Arbitrarily collected twenty-four electrochemical data for the NNO system are plotted in Fig. 4 using their differences $\left(\Delta \log \mathrm{f}_{\mathrm{O}_{2}}\right)$ from a temporary scale. These data, mostly given in the form of $\log f_{\mathrm{O}_{2}}=a-b / T$, can be averaged to a scale of $\log \mathrm{f}_{\mathrm{O}_{2}}(\mathrm{~atm})=9.08-24650 / \mathrm{T}$ (dashed line $\mathrm{M}$ in Fig. 4) by taking average for coefficients $a$ and $b$, while they appear to converge around the two points marked by circles with arrows that indicate $\pm 10 \%$ span of $\mathrm{f}_{\mathrm{O}_{2}}$ (including some scales extended out of their original temperature ranges, 13 and 15 scales cross the arrows at the left and the right marks, respectively). The $\log \mathrm{f}_{\mathrm{O}_{2}}-1 / \mathrm{T}$ relation of NNO given by the tabulated values of RHF (which we call "reference scale" for short) is also plotted as the curve RHF.

The following comments can be made with regard to Fig. 4: (1) Although the high-temperature emf method is generally accepted as an accurate one, the plotted data show a fairly large scatter. One of the possible causes giving rise to such a scatter is erratic influence of high $\mathrm{f}_{\mathrm{O}_{2}}$ reference gases or of ambient air on the low $\mathrm{f}_{\mathrm{O}_{2}}$, NNO system in the cell assembly and this implies the possibility that some of the plotted scales have been biased toward higher $\mathrm{f}_{\mathrm{O}_{2}}$. In any case, it is apparent that assertions dependent on only one or two of these data must be considered with reserve (see, for example, KELLOGG, 1969); (2) The two marks mentioned above are in good accord with the reference scale but this is not a sufficient proof for the validity of the scale; (3) If the reference scale is conformable with the plotted experimental data, a tangent (not shown) touching the curve RHF at about $1,150^{\circ} \mathrm{K}$ (i.e., an approximate median temperature for the plotted scales) should have the same slope as that of the line
M. The difference of slope now existing, then, can be interpreted as suggesting a reduction (by about $1.6 \mathrm{KJ} / \mathrm{mol}$ ) of the $\Delta \mathrm{H}_{\mathrm{f}}{ }^{\circ}$ of $\mathrm{NiO}$ given by RHF.

Independently from these and thermochemical data, a $\log \mathrm{f}_{\mathrm{O}_{2}}$ value of $\mathrm{NNO}$ at $300^{\circ} \mathrm{C}$ can be obtained as follows: The solubility of $\mathrm{H}_{2}$ in water at $300^{\circ} \mathrm{C}$ has been given by GilPatrick and STONE (1962) as $\mathrm{C}_{\mathrm{H}_{2}}=0.10996$ for 1 bar $\mathrm{H}_{2}$ partial pressure. The $\mathrm{f}_{\mathrm{H}_{2}}$ corresponding to this $\mathrm{H}_{2}$ pressure is estimated to be 1.06 (see the discussion in Kishima and SAKAI, 1984) and therefore we obtain $Y=9.6$ for hydrogen in water at $300^{\circ} \mathrm{C}$ and under the saturation vapor pressure (SVP $=85.81$ bars). The error ranges of the solubility data and the estimated $\mathrm{f}_{\mathrm{H}_{2}}$ are unknown, so we tentatively assume that the uncertainty of the $\mathrm{Y}$ value is $\pm 5 \%$. If the $\mathrm{MH}$ buffer is put in this water, the $\mathrm{C}_{\mathrm{H}_{2}}$ would be found at $3.25 \times 10^{-4}$ (within $4 \%$ error) as is estimated from the data given in Table 1, and hence the $\log \mathrm{f}_{\mathrm{H}_{2}}$ is calculated to be $-2.499 \pm 0.030$ using the above $\mathrm{Y}$ value. Under the same P-T condition, $\log \mathrm{K}_{\mathrm{W}}=19.627$ \pm 0.015 and $\log \mathrm{f}_{\mathrm{H}_{2} \mathrm{O}}=1.828 \pm 0.001$ have been given by RHF and HAAS (1970), respectively. Therefore, by using eq. (4), the $\log \mathrm{f}_{\mathrm{O}_{2}}$ of the $\mathrm{MH}$ buffer is calculated to be $-30.586 \pm 0.108$ under the SVP, or $-30.588 \pm 0.108$ under 1 bar standard pressure. As the difference of $10 \mathrm{~g}$ $\mathrm{f}_{\mathrm{O}_{2}}$ between $\mathrm{MH}$ and $\mathrm{NNO}$ buffers at $300^{\circ} \mathrm{C}$ and 1 bar is estimated to be $3.55 \pm 0.063$ (Table 2 with extrapolation), the $\log \mathrm{f}_{\mathrm{O}_{2}}$ of $\mathrm{NNO}$ is calculated to be $-34.14 \pm 0.17$, which is compared with -33.970 given by the reference scale.

This result, the two marks in Fig. 4 and the uncertainty interval of the $\log \mathrm{f}_{\mathrm{O}_{2}}$ value of $\mathrm{NNO}$ at $25^{\circ} \mathrm{C}$ as given in RHF are plotted in the lower part of Fig. 5 (bars 3, 1, 2 and 4, respectively) relative to the reference scale using the ordinate marked by $\delta_{1}$. In interpreting this plot, we have to inquire also into the credibility of the data at $25^{\circ} \mathrm{C}$.

The $\Delta \mathrm{H}_{\mathrm{f}, 298}^{\circ}$ of $\mathrm{NiO}$ adopted in $\mathrm{RHF}$ is $-239743 \pm 418 \mathrm{~J} / \mathrm{mol}(-57.3 \pm 0.1 \mathrm{kcal} / \mathrm{mol})$ which was obtained by BoYle et al. (1954). Compared to this, however, the majority of the 

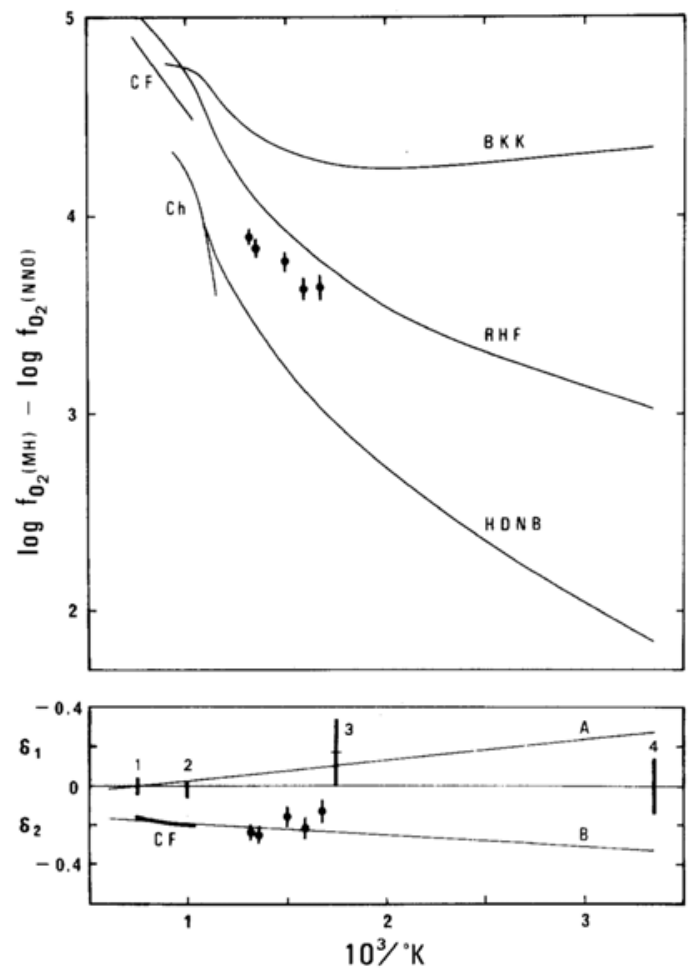

Fig. 5 (Top) Comparison of log $\mathrm{fO}_{2}$ differences between $M H$ and NNO buffer. Data sources: $C F$, CHARETTE and FLENGAS (1968); Ch, CHOU (1978); BKK, BARIN et al. (1973, 1977); RHF, ROBIE et al. (1979); HDNB, HELGESON et al. (1978); five data points are from the present study. (Bottom) $\delta_{1}: \log$ $\mathrm{fO}_{2}$ of $\mathrm{NNO}$ relative to that given by $\mathrm{RHF}$. Using this ordinate plotted are four data points with vertical bars: 1 and 2 are from Fig. 4, 3 is an estimated value at $300^{\circ} \mathrm{C}$ based on the present study (see text), and 4 is the uncertainty of $\mathrm{RHF}$ at $25^{\circ} \mathrm{C} . \quad \delta_{2}: \log f_{\mathrm{O}_{2}}$ difference between $M H$ and $N N O$ relative to that from RHF. CF and the present five data are plotted using this ordinate. For lines $A$ and $B$, see text.

data presented so far for the same quantity are more negative. For example, the N.B.S. compilation (RossinI et al., 1952) has adopted $-58.4 \mathrm{kcal} / \mathrm{mol}$ on the basis of eleven determinations, a more recent databook of BARIN and KNACKE (1973) adopts a data of $-57.5 \pm 0.5$ $\mathrm{kcal} / \mathrm{mol}$, and RUTNER and HAURY (1974) have quoted a mass spectrometric result of $-58.0 \pm 0.3 \mathrm{kcal} / \mathrm{mol}$. Though Kellogg (1969) has obtained $-57.24 \pm 0.13 \mathrm{kcal} / \mathrm{mol}$ from two sets of high-temperature emf data and a set of gas equilibrium data, a large number of emf data plotted in Fig. 4 as a whole suggest a value near $-57.7 \mathrm{kcal} / \mathrm{mol}$ as mentioned above. Thus, in order to reject these more negative data and to adopt $-57.3 \pm 0.1 \mathrm{kcal} / \mathrm{mol}$ as the best value, an additional precise calorimetric measurement of $\Delta \mathrm{H}_{\mathrm{f}, 298}^{\circ}$ of $\mathrm{NiO}$ would have to be made.

In order to compromise the above discussions on the four data points 1 to 4 in Fig. 5, we first adopt $-57.5 \mathrm{kcal} / \mathrm{mol}$ for the $\Delta \mathrm{H}_{\mathrm{f}, 298}^{\circ}$ of $\mathrm{NiO}$, secondly assume that our data of $\log \mathrm{f}_{\mathrm{O}_{2}}$ difference between $\mathrm{MH}$ and NNO buffers are true at the negative ends of the indicated error ranges and finally draw simply a straight line through the four points as indicated by line A in Fig. 5. In this way, the correction to be added to the reference scale is estimated to be $\delta \log \mathrm{f}_{\mathrm{O}_{2}}=$ $0.08-106 / \mathrm{T}$.

The present data for the $\log \mathrm{f}_{\mathrm{O}_{2}}$ difference between $\mathrm{MH}$ and NNO buffers are compared with some experimental and calculated results in Fig. 5 (top). Electrochemical data of Charette and Flengas (1968) obtained with a cell composed of a pair of $\mathrm{MH}$ and $\mathrm{NNO}$ buffers are supposed to be highly accurate. Our results are in good accord with the extension of these data, but not so good with CHou's (1978) data which were obtained by the 'Ag-AgCl hydrogen sensor' method, and are closest to RHF among the thermodynamic calculations, less close to HeLGESON et al. (1978) and far from BARIN et al. (1973, 1977). Helgeson et al. (1978) have used the CHOU's data to retrieve the $\Delta \mathrm{G}_{\mathrm{f}, 298}^{\circ}$ of hematite and therefore the coincidence between their results is quite natural.

The above $\log \mathrm{f}_{\mathrm{O}_{2}}$ difference data of us and of Charette and Flengas (1968) are replotted at the bottom of Fig. 5 (using the ordinate marked by $\delta_{2}$ ) relative to the same difference given by RHF. Recalling the above interpretation of our data, we can draw a straight B through the plotted data. The difference between the lines $\mathrm{A}$ and $\mathrm{B}$ gives the correction, $\delta \log \mathrm{f}_{\mathrm{O}_{2}}=-0.05-160.5 / \mathrm{T}$, to be 
applied to the $\log \mathrm{f}_{\mathrm{O}_{2}}-1 / \mathrm{T}$ relationship of $\mathrm{MH}$ buffer given by RHF. Provided that the heat capacity equations of magnetite and hematite given in RHF are free from errors, this correction indicates increase of $3,070 \mathrm{~J} / \mathrm{mol}$ in the $\Delta \mathrm{H}^{\circ}$ and decrease of $-1.0 \mathrm{~J} / \mathrm{mol} \mathrm{K}$ in the $\Delta \mathrm{S}^{\circ}$ for reaction (1). These corrections are small compared to the corresponding uncertainties given by RHF, $\pm 15,898 \mathrm{~J} / \mathrm{mol}$ and $\pm 2.94 \mathrm{~J} / \mathrm{mol} \mathrm{K}$, respectively. The corrected $\log$ $\mathrm{f}_{\mathrm{O}_{2}}-1 / \mathrm{T}$ scale of $\mathrm{MH}$ buffer is compared in Fig. 6 with some reported ones. The validity of our

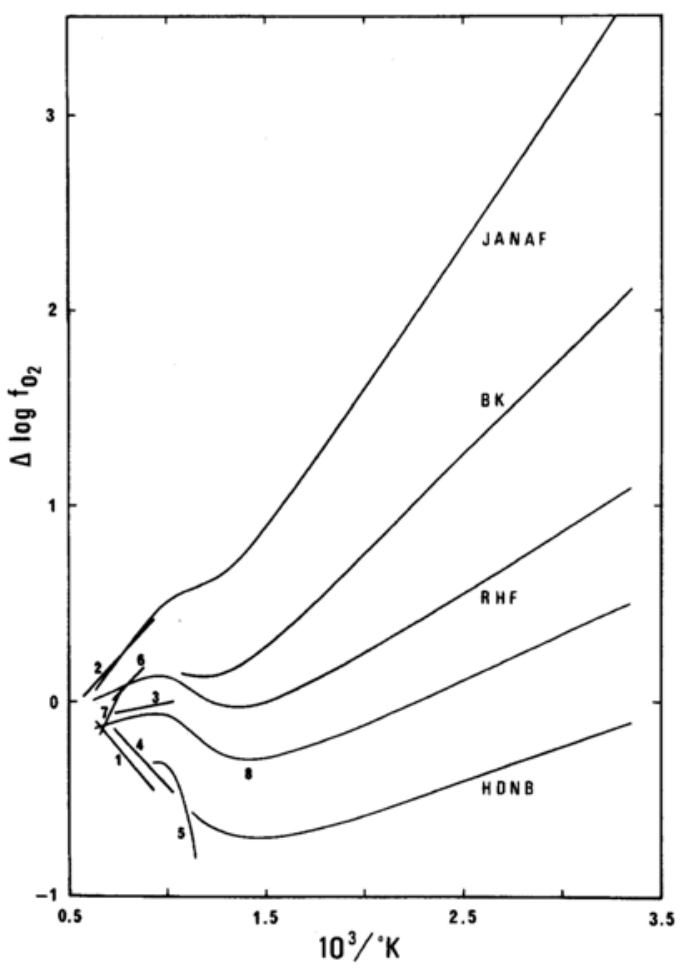

Fig. 6 Comparison of $\log f_{\mathrm{O}_{2}}-1 / T$ relations of $\mathrm{MH}$ buffer. $\Delta \log \mathrm{fO}_{2}$ denotes the difference from a temporary scale: $\log \mathrm{fO}_{2}(\mathrm{~atm})=15-26000 / T$. Data sources: 1, SCHMAHL (1941); 2, NORTON (1955) quoted by EUGSTER and WONES (1962); 3, CHARETTE and FLENGAS (1968); 4, MORIYAMA et al. (1969); 5, CHOU (1978); 6, SCHWAB and KÜSTNER (1982), 7, MYERS and EUGSTER (1983); 8, this work; JANAF, STULL and PROPHET (1971); BK, BARIN and KNACKE (1973); RHF, ROBIE et al. (1979); HDNB, HELGESON et al. (1978). scale is demonstrated in a related paper (Kishima and SAKaI, 1983), which shows con sistency between the $\mathrm{Y}$ values (for temperatures between 296 to $487^{\circ} \mathrm{C}$ ) derived from the $\mathrm{C}_{\mathrm{H}_{2}}$ data in Table 1 and the new scale, and the $\mathrm{Y}$ values for lower and higher temperature ranges which are derived from other sorts of data.

The $\log \mathrm{f}_{\mathrm{O}_{2}}$ value of FMQ buffer at $487^{\circ} \mathrm{C}$ is calculated to be $-24.01( \pm 0.09)$. This is obtained by combining the $\log \mathrm{f}_{\mathrm{O}_{2}}$ value of $\mathrm{MH}$ at $487^{\circ} \mathrm{C}$ given by RHF $(-19.230)$, the correction for the $\mathrm{MH}$ buffer determined above and the $\log \mathrm{f}_{\mathrm{O}_{2}}$ difference between FMQ and $\mathrm{MH}$ buffer measured in the present study. The result is compared in Fig. 7 with some reported experimental data (CHOU, 1978; Wones and Gilbert, 1969; HewItT, 1978; SCHWAB and KÜSTNER, 1981; MYERS and EUGSTER 1983) and calculated $\log \mathrm{f}_{\mathrm{O}_{2}}-1 / \mathrm{T}$ relationships of FMQ (RoBIE et al., 1979, 1982; HELGESON et al., 1978). Our data point is concordant

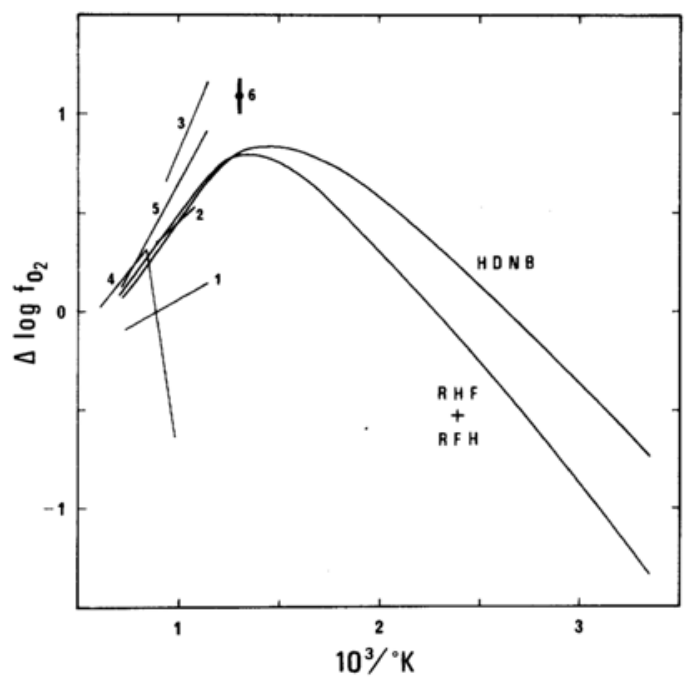

Fig. 7 Comparison of $\log \mathrm{fO}_{2}-1 / \mathrm{T}$ relations of $\mathrm{FMQ}$ buffer. $\Delta \log \mathrm{fO}_{2}$ denotes the difference from a temporary scale: $\log \mathrm{fO}_{2}$ (bar) $=9.5-26300 / T$. Data sources: 1, WONES and GILBERT (1969); 2, HEWITT (1978); 3, CHOU (1978); 4, SCHWAB and KÜSTNER (1981); 5, MYERS and EUGSTER (1983); 6, this work; HDNB, HELGESON et al. (1978); RHF + RFH, ROBIE et al. (1979, 1982). 
with the recent data of MYERs and EUGSTER (1983) and less but fairly concordant with the scales of CHOU (1978), HewitT (1978) and SchwaB and Kústner (1981) (the hightemperature branch of their scale). From these five data, the correction to be applied to the $\log \mathrm{f}_{\mathrm{O}_{2}}-1 / \mathrm{T}$ relationship of FMQ given by RoBIE et al. $(1979,1982)$ is roughly evaluated as $\delta \log \mathrm{f}_{\mathrm{O}_{2}}=-0.3+460 / \mathrm{T} \pm 0.2$.

Acknowledgements-We are very grateful to F.W. DICKSON for giving us instructions in the construction of our Dickson-type apparatus. This work was financially supported by the Grant in Aid for Scientific Research, Nos. 410912, 434028 and 57430010, from the Ministry of Education, Japan.

\section{REFERENCES}

ALCOCK, C.B. and BELFRED, T.N. (1964) Thermodynamics and solubility of oxygen in liquid metals from electromotive force measurements involving solid electrolytes. I. Lead. Trans. Faraday Soc. 60, 822-835.

ANTILL, J.E. and WARBURTON, J.B. (1967) Oxidation of nickel by carbon monoxide. J. Electrochem. Soc. 114, 1215-1221.

B.ARBI, G.B. (1964) Thermodynamic functions and phase stability limits by electromotive force measurements on solid electrolytic cells. J. Phys. Chem. 68, 1025-1029.

BARIN, I. and KNACKE, O. (1973) Thermodynamical properties of inorganic substances, Springer-Verlag, Berlin.

BARIN, I., KNACKE, O. and KUBASCHEWSKI, O. (1977) Thermodynamical properties of inorganic substancesSupplement, Springer-Verlag, Berlin.

BERgLUND, S. (1976) The free energy of formation of nickel oxide. Ber. Bunsenges. Phys. Chem. 80, 862-866.

BOYLE, B.J., KING, E.G. and ConwAY, K.C. (1954) Heats of formation of nickel and cobalt oxides (NiO and $\mathrm{CoO}$ ) by combustion calorimetry. J. Am. Chem. Soc. 76, 3835-3837.

Charette, G.G. and Flengas, S.N. (1968) Thermodynamic properties of the oxides of $\mathrm{Fe}, \mathrm{Ni}, \mathrm{Pb}, \mathrm{Cu}$, and $\mathrm{Mn}$, by emf measurements. J. Electrochem. Soc. 115, 796-804.

CHOU, I-M. (1978) Calibration of oxygen buffers at elevated $\mathrm{P}$ and $\mathrm{T}$ using the hydrogen fugacity sensor. Am. Mineral. 63, 690-703.

EUGSTER, H.P. and WONES, D.R. (1962) Stability relations of the ferruginous biotite, annite. J. Petrol. 3, 82-125.

FischeR, W.A. and PATEISKY, G. (1970) Die Eignung fester Metall-Metalloxid-Gemische als Bezugspotentiale in Sauerstoffmesszellen. Arch. Eisenhuettenw. 41, 661-673.

FLASCHEN, S.S. and OSBORN, E.F. (1957) Studies of the system iron-silica-water at low oxygen partial pressures. Econ. Geol. 52, 923-943.

FOURNIER, R.O. and POTTER, R.W. (1982) An equation correlating the solubility of quartz in water from $25^{\circ}$ to $900^{\circ} \mathrm{C}$ at pressures up to 10,000 bars. Geochim. Cosmochim. Acta 46, 1969-1974.

GilPatRicK, L.O. and STONE, H.H. (1962) Gasliquid equilibria. Oak Ridge Natl. Lab. Rep. ORNL3262, 64-66.

HAAS, J.L., JR. (1970) Fugacity of $\mathrm{H}_{2} \mathrm{O}$ from $0^{\circ}$ to $350^{\circ} \mathrm{C}$ at the liquid-vapor equilibrium and at 1 atmosphere. Geochim. Cosmochim. Acta 34, 929-932.

Helgeson, H.C., Delany, J.M., Nesbitt, H.W. and BIRD, D.K. (1978) Summary and critique of the thermodynamic properties of rock-forming minerals. Am. J. Sci. 278A, 1-229.

HEWITT, D.A. (1978) A redetermination of the fayalite-magnetite-quartz equilibrium between $650^{\circ}$ and $850^{\circ}$ C. Am. J. Sci. 278, 715-724.

HuEBNER, J.S. and SATO, M. (1970) The oxygen fugacity-temperature relationships of manganese oxide and nickel oxide buffers. Am. Mineral. 55, 934-952.

IWASE, M., FUJIMURA, K. and MORI, T. (1975)

Thermodynamic study on liquid lead-silver alloys. Nippon Kinzoku Gakkaishi 39, 1118-1127 (in Japanese).

JACOBSSON, E. and ROSÉN, E. (1981) Thermodynamic studies of high temperature equilibriums. 25. Solid state emf studies of the systems ironferrous oxide, nickel-nickelous oxide, and cobaltcobaltous oxide in the temperature range 1000 1600 K. Scand. J. Metall. 10, 39-43.

KELLOGG, H.H. (1969) Thermodynamic properties of the oxides of copper and nickel. J. Chem. Eng. Data 14, 41-44.

Kemori, N., Katayama, I. and Kozuka, Z. (1979) Measurements of standard molar Gibbs energies of formation of nickel (II) oxide, copper (I) oxide, and cobalt (II) oxide from solid and liquid metals and oxygen gas by an e.m.f. method at high temperatures. J. Chem. Thermodyn. 11, 215-228.

KENNEDY, G.C. (1950) A portion of the system silica-water. Econ. Geol. 45, 629-653.

KISHIMA, N. and SAKAI, H. (1984) Fugacityconcentration relationship of dilute hydrogen in 
water at elevated temperature and pressure. Earch Planet. Sci. Lett. 67, 79-86.

KiUKKOLA, K. and WAGNER, C. (1957) Measurements of galvanic cells involving solid electrolytes. J. Electrochem. Soc. 104, 379-387.

KLINEDINST, K.A. and STEVENSON, D.A. (1972) The determination of the standard Gibbs energy of formation of $\beta$-gallium sesquioxide from e.m.f. measurements using an yttria-doped thoria electrolyte. J. Chem. Thermodyn. 4, 565-573.

MARKIN, T.L. and BONES, R.J. (1962) The determination of changes in free energy for uranium oxides using a high-temperature galvanic cell. I. At. Energy Res. Estab. (Gt. Brit.) Rept. AERE-R 4042.

Moriyama, J., Sato, N., ASaO, H. and Kozuka, Z. (1969) Thermodynamic study on systems of metals and their oxides by electromotive force measurements using solid electrolytes. Mem. Fac. Eng., Kyoto Univ. 31 (Pt. 2), 253-267.

Moser, Z., FITZNer, K. and ZAKULSKI, W. (1975) Free energy of formation of $\mathrm{NiO}$ and $\mathrm{Cu}_{2} \mathrm{O}$ by EMF measurements involving solid electrolytes. Bull. Acad. Pol. Sci., Ser. Sci. Tech. 23, 7-12.

MYERS, J. and EUGSTER, H.P. (1983) The system Fe-Si-O: oxygen buffer calibrations to $1,500 \mathrm{~K}$. Contrib. Mineral. Petrol. 82, 75-90.

MYERS, J. and GUNTER, W.D. (1979) Measurement of the oxygen fugacity of the cobalt-cobalt oxide buffer assemblage. Am. Mineral. 64, 224-228.

NORTON, F.J. (1955) Dissociation pressures of iron and copper oxide. General Electric Res. Lab. Rep. No. 55-RL-1248.

OISHI, T., HiRuma, T. and MoRIYAMA, J. (1972) Thermodynamic studies of molten copper-tin alloys using solid electrolytes. Nippon Kinzoku Gakkaishi 36, 481-485 (in Japanese).

PIZZINI, S. and MORLOTTI, R. (1967) Thermodynamic and transport properties of stoichiometric and nonstoichiometric nickel oxide. J. Electrochem. Soc. 114, 1179-1189.

RoBIE, R.A., FINCH, C.B. and HEMINGWAY, B.S. (1982) Heat capacity and entropy of fayalite $\left(\mathrm{Fe}_{2} \mathrm{SiO}_{4}\right)$ between 5.1 to $383 \mathrm{~K}$ : comparison of calorimetric and equilibrium values for the QFM buffer reaction. Am. Mineral. 67, 463-469.

RoBIE, R.A., HEMINGWAY, B.S. and FISHER, J.R. (1979) Thermodynamic properties of minerals and related substances at $298.15 \mathrm{~K}$ and 1 Bar ( $10^{5}$ Pascals) pressure and at higher temperatures. U.S. Geol. Survey Bull. 1452.

Rossini, F.D., WAGMan, D.D., Evans, W.H., LEVINE, S. and JAFFE, I. (1952) Selected values of chemical thermodynamic properties. Natl. Bur. Standards Circular 500.

RUTNER, E. and HAURY, G.L. (1974) Nickel-NiO thermodynamic cycle: values of $\Delta \mathrm{G}^{\circ}$ and $\Delta \mathrm{H}^{\circ}$. J. Chem. Eng. Data 19, 19-27.

RYTUBA, J.J. and DICKSON, F.W. (1974) Reaction of pyrite + pyrrhotite + quartz + gold with $\mathrm{NaCl}$ $\mathrm{H}_{2} \mathrm{O}$ solutions, $300-500^{\circ} \mathrm{C}, 500-1,500$ bars, and genetic implications. Proc. 4th Int. Assoc. Genesis Ore Deposists Symp., Verna, 2, 320-326.

SCHMAHL, N.G. (1941) Die Beziehung zwischen Sauerstoffdruck, Temperatur und Zusammensetzung im System $\mathrm{Fe}_{2} \mathrm{O}_{3}-\mathrm{Fe}_{3} \mathrm{O}_{4}$. Z. Elektrochem. 47, 821835.

SCHWAB, R.G. and KUSTNER, D. (1981) Die Gleichgewichtsfugazitäten technologisch und petrologisch wichtiger Sauerstoffpuffer. Neues Jahrb. Mineral. Abh. 140, 111-142.

SELleRS, C.M. and MAAK, F. (1966) Thermodynamic properties of solid $\mathrm{Au}-\mathrm{Ni}$ alloys at 775 to $935^{\circ}$ C. Trans. Met. Soc. AIME 236, 457-464.

SEYFrIED, W.E., JR., GORDON, P.C. and DICKSON, F.W. (1979) A new reaction cell for hydrothermal solution equipment. Am. Mineral. 64, 646-649.

STAFFORD, S.W. and MCLELLAN, R.B. (1974) The solubility of hydrogen in nickel and cobalt. Acta Met. 22, 1463-1468.

STEELE, B.C.H. and ALCOCK, C.B. (1965) Factors influencing the performance of solid oxide electrolytes in high-temperature thermodynamic measurements. Trans. Met. Soc. AIME 233, 1359 1367.

STULL, D.R. and PROPHET, H. (1971) JANAF thermodynamical tables (2nd ed.). Natl. Bur. Standards.

TAYLOR, R.W. and SCHMALZRIED, H. (1964) The free energy of formation of some titanates, silicates, and magnesium aluminate from measurements made with galvanic cells involving solid electrolytes. J. Phys. Chem. 68, 2444-2449.

TRE TJAKOV, J.D. and SCHMALZRIED, H. (1965) Zur Thermodynamik von Spinellphasen (Chromite, Ferrite, Aluminate). Ber. Bunsenges. Phys. Chem. 69, 396-402.

VASIL'EVA, I.A., SuKhushina, I. S., GRANOVSKaYA, ZH. V., BALABAEVA, R.F. and MaIOROVA, A.F. (1975) Thermodynamic properties of oxides $\mathrm{NbO}, \mathrm{Fe}_{0.95} \mathrm{O}, \mathrm{CoO}, \mathrm{NiO}, \mathrm{Cu}_{2} \mathrm{O}$ and $\mathrm{CuO}$-comparison of electrodes in the electromotive force method. Zh. Fiz. Khim. 49, 2169-2174 (in Russian).

WONES, D.R. and GILBERT, M.C. (1969) The fayalite-magnetite-quartz assemblage between $600^{\circ}$ and $800^{\circ}$. Am. J. Sci. 267A, 480-488. 